\title{
Net Promoter Score - An Evaluation of Top Companies in On-line Retailing in India
}

\author{
R. Sugant \\ Shri Dharmasthala Manjunatheshwara (SDM) Institute for Management Development, \\ Siddhartha Layout, Mysuru - 570011, Karnataka, India; sugant@sdmimd.ac.in
}

\begin{abstract}
A major tool that is used to measure the customer satisfaction and loyalty in organisation is "Net Promoter Score (NPS)", which tends to assess the loyalty through one question "On a scale of zero-to-ten, how likely is it that you would recommend us to a friend or colleague"? Based on the ratings given by the above questions, NPS classifies customers into three typespromoters, passives and detractors. NPS score is defined as "\%promoters - \%detractors". NPS as a tool is also being used by several Indian companies across the spectrum to measure customer satisfaction and loyalty. However, the data regarding the same is not publicly available for customers to make an informed decision. This research aims at bridging this gap by assessing NPS with regard to on-line retailing in India.
\end{abstract}

Keywords: Customer Satisfaction, Loyalty, Net Promoter Score (NPS), On-Line Ecommerce, On-Line Retailing

\section{Introduction}

They say "A satisfied customer is the best source of advertisement". But how do we know if the customer is satisfied or not? Even if the customer is satisfied, will she remain loyal to the company? Will she continue to purchase more in future? Will she refer the company/product/brand to her friends and relatives? These are some of the questions that give sleepless nights to sales/marketing and business heads of companies.

In the present VUCA world, where hyper competition is witnessed in most of the industries, every customer is critical for the company's survival. Specifically in service industries, where the offering is intangible and quality is a matter of perception, the companies are struggling to retain customers. Across the industry - be it telecom, e-commerce, retail or banking - customer loyalty has been falling and retaining customers is becoming a big challenge. It was proved by several research studies that customer satisfaction is an antecedent to customer loyalty (Fornell, et al., 1996; Auh, et al., 2003; Coker, 2013). Hence it becomes highly important to measure customer satisfaction on a regular basis and preferably as and when customer comes in contact with the service provider. Obviously, the customers will have neither the time nor the inclination to fill up a long research instrument with multiple questions every time they come in contact with the company/service provider.

Fred Reicheld and his colleagues at consulting firm, Bain \& Co was fixated with this problem and based on their extensive study came up with a simple tool "Net Promoter Score (NPS)". Net Promoter Score or NPS evaluates the customer satisfaction and thus loyalty by one question - "How likely is it that you would recommend this company to a friend or colleague?"

Speaking about the Indian context, there is a speculation that people in India don't rate the organisations high. But it is not true. Indians are generous in rating the 
companies relatively higher than most nations. Quoting few examples, a company named Health Spring chain of primary healthcare clinics spread across Mumbai and Pune, uses NPS daily in their operations and they measure NPS score in real time. Reliance Jio is India's first national 4G-network provider. When they set about defining the kind of world-class customer experience they wanted to provide, they realized they'd need to look further than their own borders. They started working in India to create the largest single customer services operation in Asia, capable of serving 200 million customers in the first 18 months. Closed loop NPS is at the heart of the empowered way agents deliver exceptional services.

The purpose of this research is to assess the NPS scores of leading service providers in on-line retail. The research will also try and identify the factors that customers find to be providing highly satisfying or dissatisfying experience in online retail.

\section{Literature Review}

\subsection{Customer Satisfaction and Loyalty}

The three primary satisfaction components described are benefit satisfaction, economic satisfaction and social satisfaction. Customers basically seek these components when they buy a product or service.

York, et al. (2011) says that consumer satisfaction research began in the marketing field in the 1970s and is currently based on the "disconfirmation of expectations paradigm". This paradigm says consumer brand evaluation involves comparing actual performance with some standard. While comparing, three outcomes are likely:

1. Confirmation, where performance matches standards, leading to neutral feelings.

2. Positive disconfirmation, where performance is deemed better than standard, resulting in satisfaction.

3. Negative disconfirmation, where performance is deemed worse than standard, resulting in dissatisfaction.

In one of the earliest definitions, Churchill and Suprenant (1982) define customer satisfaction as "an outcome of purchase and use resulting from the buyers' comparison of the rewards and costs if the purchase in relation to the anticipated consequences". Their research showed that for a durable product, satisfaction was solely affected by performance of the product.

While the initial studies on customer satisfaction focussed on products, the earliest research on customer satisfaction in service industry (restaurant dining) was done by Cadotte, et al. (1987). Their research showed that customers use expectations as a standard to evaluate their satisfaction. In addition, experience-based norms are also used by customers to evaluate their satisfaction. Also no one evaluation standard can be used to assess the satisfaction and the standard might vary between services.

Customer satisfaction is defined by Oliver (2010) as "Satisfaction is the consumer's fulfilment response. It is a judgement that a product/service feature, or the product or service itself, provided (or is providing) a pleasurable level of consumption related fulfilment, including levels of under or over fulfilment."

Klopotan, et al. (2016) say customer relationship management has a great role in customers' loyalty and satisfaction. Loyalty can be defined as dedication to purchase preferred product irrespective of situational changes or marketing effort. Loyalty is defined through three dimensions: brand loyalty, behavioural loyalty and situational loyalty. Brand loyalty presents re-buying preferred product constantly in the future. Attitudinal loyalty is connected with a brand, accustomed by positive client attitudes towards specific brand. Behavioural loyalty is presented by revealed buying and usage behaviour, accustomed by client satisfaction. The authors also say situational loyalty depends upon shopping and purchasing situation at one specific moment.

While focussing on establishing and sustaining customer loyalty, McMullan (2008) says that customers who have high and medium levels of loyalty react positively by the recognition of the company and believe in reciprocal relationship supported by unique rewards. While customers who are at the lower end of loyalty are not interested in relationship with the company, they are keen on availing promotional offers of the company.

The research by Jana (2014) proves that service quality is an antecedent to customer satisfaction which in turn is an antecedent to customer loyalty. Jamal and Anastasiadou (2009) also reiterate the relationship between service quality and customer satisfaction and customer satisfaction and loyalty. The authors say that reliability, tangibility and empathy are positively related 
to customer satisfaction and loyalty, while expertise is negatively related to loyalty.

The study by Kursunluoglu (2014) on shopping centre loyalty showed that four factors affected customer loyalty. These are: 1 . customer services about atmosphere, 2 . incentive customer services, 3 . customer services in encounter stage, and 4. customer services about payment. While factors: 2., 3. and 4. affected only customer loyalty and not customer satisfaction, whereas factor (1) affected both satisfaction and loyalty.

According to Edvardsson, et al. (2000), customers' loyalty is defined as customers' predisposition to repurchase from the same firm or same brand over time. Loyalty can be due to various factors like, switching costs, positive word-of-mouth, meeting expectations, service quality etc., which are correlated to customer satisfaction. The concept of 'spuriously loyal' customers makes it logical to deduce that some customers remain with service providers due to switching costs implications. Switching costs are incurred when customers switch to other providers. Therefore, switching costs restrain customers from exiting a provider as a result of inconveniencies, penalties, psychological costs, among others. Word-ofmouth may be positive or negative; however, a positive word-of-mouth occurs when current customers are willing to recommend to others.

According to a research conducted by Shrivastava, et al. (2012) where structural equation model was used to analyse effects of customers 'perceived service quality, showed that trust, and customer satisfaction drive customer loyalty in telecommunication industry. The results of the study indicate that trust and customer satisfaction are significantly and positively related to customer loyalty. Also the study found customer satisfaction to be an important mediator between perceived service quality and customer loyalty.

The study by Zameer (2015) shows that: "there is a positive relation between the service quality, customer satisfaction and corporate image". Their study also showed that service quality, customer satisfaction and corporate image has a high influence on the customer perceived value.

E-commerce has become a disruptive force in not only the retail industry but also in industries like traveling, banking, media, hospitality etc. Bhattacharya and Mishra (2015) say that the factors responsible for growth of
E-commerce in India are: growth in internet Usage, use of plastic money, use of devices, growth in disposable income etc. The challenges faced by e-commerce players are: merchandise return, penetration of internet, problem of payment gateways, infrastructural issues, cash on delivery as the preferred mode etc. They say that if these challenges are managed better, service quality will improve which in turn will result in increased customer loyalty.

\subsection{Net Promoter Score - The Tool}

A major tool that is used to measure the customer satisfaction and loyalty in organisation is NPS. The key architect of the tool is Fred Reicheld, a Fellow at Bain \& Company. In the book "The Ultimate Question 2.0", Reicheld and Markey (2011) have thrown light on NPS, and show how to approach business through good profits by ethical means instead of bad profits just by exploiting the customers.

The authors of NPS say that the satisfaction and loyalty of a customer towards a product/service can be ascertained by asking just one question:

"On a scale of zero-to-ten scale, how likely is it that you would recommend us to a friend or colleague?"

Based on the ratings given by the customers to the above question, NPS classifies customers into 3 types:

1. Promoters: People who rate the company 9 or 10 and are very loyal to the company and spread a positive word of mouth.

2. Passives: People who rate the company 7 or 8 , passively satisfied. They neither talk good or bad about the company.

3. Detractors: People who rate 6 or below, who are very dissatisfied, dismayed about their encounter with the company.

Based on this simple survey, according to the authors, Net Promoter Score can be defined as: NPS $=\%$ promoters - \% detractors

The authors claim that this metric is simple, powerful and easy to understand. The authors show how to use the Golden Rule - treating others as you'd want to be treated - to do this and thrive in a customer-driven world through profitable customer relationships. The authors cite a lot of examples about the companies which were customer centric and making good profits. Among which 
were Zappos, Walmart etc., had great revenue models keeping the customers in the centre. The authors claim that how a company connects to the customers makes that connection worthy for the company which in turn will result in spending less on the advertising. This is because the customers themselves recommend and promote the company to their friends and colleagues.

The companies can also add one more open ended question to the survey.

"What is the primary reason for your score?"

According to the authors, NPS is for companies that treat customer loyalty as a strategic priority. The data says a firm can increase their revenue $25-100 \%$ with an increase in retention rate. But, to ensure retention rates, the company has to build worthy relationships with the customers, and it does not come for free. The company needs to invest on retaining customers and reduce reliance on bad profits. The question is, how to convert a detractor into passive or promoter, and would it be worthy to raise the relative NPS by 10 points.

The authors cite the examples of quite a few companies that have adopted NPS and have seen phenomenal results. A few of them are as below:

Charles Schwab Corporation: Post implementing NPS, the company has seen the score improve from $-35 \%$ to $+35 \%$ and the company also regained its leadership position in the industry.

Apple: Apple stores began measuring NPS when they had 163 stores. The NPS then was 58\%, which improved to $70 \%$ when the score count became 320 . The best stores have been achieving an NPS of 90\%. Consequently, Apple's revenue is estimated at $\$ 6000$ per square foot compared to other electronics store whose revenue stood at $\$ 1200$ per square foot.

Ascension Health: The largest Catholic not-for-profit healthcare system in US operated 78 hospitals with operating revenues of $\$ 14.8$ billion. When they started implementing NPS, the best and worst scores for its unit hospitals were 83 and 21. Post implementing NPS, the score jumped to 93 and 40. System-wide performance improved from $58 \%$ to $68 \%$ that clearly shows the improvement in patient satisfaction.

Rackspace: NPS helped this San Antonio based tech company to weather the financial crisis of 2008. Thanks to NPS, the company went on an overdrive to connect with passives and detractors post the crisis. This helped to increase the NPS score by 20 points to $63 \%$. Customer churns rates also declined by more than a third from $3 \%$ to $1.9 \%$.

Overall, NPS leaders in the US (companies with the highest NPS scores in their category) grow at over twice the rate of the category average.

\subsection{Net Promoter Score - A Critical Evaluation}

Bendle and Bagga (2016) analysed the efficacy of NPS as marketing metric. The author says that though the metric is quite simple to implement, it comes with its own perils. The authors opine that in order to get a high "recommendation" score, the company will have to sacrifice profits, especially in an inelastic industry. The authors cite the scaling as another problem. Also not much of study was done on NPS by academic researchers due to the difficulty of forming control group. The authors finally conclude that "critics of NPS have not been able to definitively show that NPS doesn't work; nor have supporters definitively shown that it does work".

Keiningham, et al. (2008) through their research tested the two key claims of NPS viz., whether: a) NPS can be the single most reliable indicator of a company's ability to grow, and b) whether NPS is superior to other customer satisfaction measures. The authors studied the data published by NCSB (Norwegian Customer Satisfaction Barometer) with the revenue growth or fall of the company. They found that the satisfaction and/ or loyalty metrics of NCSB were significantly correlated with the relative change in revenue of the company in a particular industry, thus disproving that the claim that NPS alone can be the single most reliable indicator of company's growth. The authors studied the American Customer Satisfaction Index (ASCI) data vis a vis NPS data with respect to recommend and repurchase intent and behaviour. The authors found that with NPS data, there was only weak correlation between recommend intent and repurchase behaviour. The disproved the second claim that NPS is superior to other customer satisfaction measures.

According to Faltejsková, et al. (2016) in the current global economic conditions, which is unsteady, turbulent and tumultuous, it is important to alter the course business to more execution oriented. As it is likewise a 
customer arranged market, to exceed expectations in the execution factor, it is particularly important to know and comprehend where the organization remains in the customer perspective. NPS is utilized not just as a pointer for the customer satisfaction and loyalty estimation, yet additionally has a considerably more extensive use as an administration framework. The NPS isolates the customers into 3 classifications, promoters, spoilers and passives. In view of the social contrasts amongst America and Europe the NPS estimation is lower in Europe than it is in US. NPS ends up being best fit for the customer satisfaction metric and loyalty marker. NPS depends on customer communication and input. This expands the connection between customer, workers and the management thus building upon execution of management strategy.

Žnidar, et al. (2014) speaks about nautical tourism in Croatia and the use of NPS there. NPS has been shown to be better in measuring pertinent states of mind of the customer and also was found to be an intense indicator of conduct loyalty. The authors found that the factor "belongingness to community" strongly correlates to satisfaction and thus tourist loyalty in the area of nautical tourism. Though the authors used multiple factor customer satisfaction study to determine the loyalty, they conclude that recommendation intention measured through NPS can be used as a proxy for loyalty.

Alhassan, et al. (2016) speaks about using NPS in healthcare industry in Ghana. NPS is an indicator used to determine the possibility of the healthcare client recommending the health facility to a fellow client (e.g., relative, friend or co-worker) based on their personal experiences of the quality of health service delivery. The authors used NPS in addition to nine other healthcare quality factors. The authors found that NPS was quite useful in predicting the likelihood of community members recommending their nearest health facility to friends and relatives.

Sharif (2008) while studying the pharmaceutical sector in UK throws light on the impact of ICT (information and communication technology) on the sales representative's internal and external relationships. The authors aver that NPS can be used to identify the customers who are least likely to defect (promoters) and also weed out the least profitable customers (detractors). ICT can be a clear enabler in implementing NPS in the pharmaceutical industry.
Aksoy (2014) opines that customer satisfaction measures and NPS are poor predictors of customers' share of deposits. The author says that it is not absolute satisfaction that determines customers' share of deposits, but the relative satisfaction vis a vis other banks that the customers use. Instead of customer satisfaction measures and NPS, the author used the "Wallet Allocation Rule (WAR)" approach which determines the customers' share of deposits in a particular bank. The WAR is based on relative ranking of different firms/brands that the customers use.

Mittal (2016) in a retrospective study of customer satisfaction between the years 1998 and 2016 finds that to disconnect between customer satisfaction and loyalty has not been adequately explained or bridged. The author feels that NPS has penetrated into the customer satisfaction/ loyalty research and most of the researchers now include "likely to recommend" measure. However he surmises that in addition to "likely to recommend", "repatronage intention" should also be measured.

Pollák and Dorcak (2016) measured the NPS scores of e-commerce companies in Slovakia. The authors found that the NPS scores of all the major players were negative - from $-15 \%$ to $-61 \%$. The study also identified factors that the customers look for in e-commerce website. A study by Jang, et al. (2013) showed that in a retail setting, "the effects of relationship quality on store loyalty are greater on groups with higher NPS". The study also showed that the effects of satisfaction and reliability on store loyalty were greater on groups with higher NPS.

Perkins (2012) tried to bring link between the dissatisfaction and complaining behaviour and the variables that causes these are attitudinal, normative, personal and situational factors. Grisaffe (2007) suggests a one-dimensional Net Promoter Score. But also says that the NPS is weak in multi-dimensional attribute. The writers of the paper say that price is a sensitive and yet important part of decision making process. It is found that very expensive products and services is very likely to draw complaints than very low priced goods.

The pros and cons are explained as:

Pro: It's simple. Fans and critics alike praise the benefits of understanding one number that's derived from an easy to understand formula. Fred Reichheld, one of the co-founders of the score who made it famous with 
his book "The Ultimate Question," argues that research among thousands of customers in different industries tied the New Promoter question to the most referrals and repeat purchases - and that the "ultimate question" can be the key metric for measuring success. And for busy executives who often get confused by market researchers' analysis, claims are that it can be a Godsend.

Con: It's too simple. The Net Promoter site will say that measuring one number alone will not lead to success and will supply customers with an operational model, white papers, online forums, Webinars and even conferences to get you to a successful score. But one number isn't enough, critics argue. "It doesn't identify problems; it doesn't offer solutions," says Charlie Scott of Woodland, O'Brien \& Scott, a customer satisfaction and management consultancy.

For all its advantages and disadvantages, Net Promoter Score is a very popular tool and accepted by companies across the world to measure customer satisfaction and loyalty. A few global companies that have adopted NPS are as below (Source: https://www.netpromotersystem. com/about/companies-that-use-net-promoter/):

\section{Airlines}

- Delta Airlines

- Southwest Airlines

- Qantas

- JetBlue

\section{Consumer products}

- $\quad P \& G$

- Lego

- Grohe

\section{Healthcare}

- Johnson \& Johnson

- Novartis

- Cigna

- Express

\section{Telecom}

\section{- AT\&T}

- T-Mobile
- Verizon

- Vodafone

- Orange

Retail

- Best Buy

- Home Depot

- Zappos

\section{Technology}

- Amazon

- Apple

- Facebook

- HP

- Logitech

- SAP

- Dell

\section{Financial Services}

- Allianz

- Citigroup

- $\mathrm{HSBC}$

- ING

- American

\section{Research Design}

\subsection{Statement of Problem}

NPS surveys are routinely conducted by Bain \& Co and other third party companies (as part of syndicated research) in US and other developed economies. For example the Jan/Feb 2018 survey by Bain \& Co, US indicates the following scores for the best and worst performing brands (large companies category) in a few select industries (based on the data available Table 1).

NPS as a tool is also being used by several Indian companies across the spectrum to measure customer satisfaction. However, the data regarding the same is not publicly available for customers to make an informed decision. This research will aim at bridging this gap. This research will focus on on-line retail. 
Table 1. NPS Scores of select Industry Sectors

\begin{tabular}{|l|l|l|l|l|l|}
\hline \multirow{2}{*}{ Industry } & \multicolumn{2}{|l|}{ Best Performer } & \multicolumn{2}{l}{ Worst Performer } & \multirow{2}{*}{$\begin{array}{l}\text { Average } \\
\text { Industry Score }\end{array}$} \\
\cline { 2 - 6 } & Company & Score & Company & Score & \\
\hline Retail & Trader Joe's & 62 & Morrisons & 2 & 29 \\
\hline Internet & Flipkart & 70 & $\begin{array}{l}\text { Wayfair } \\
\text { LLC }\end{array}$ & 23 & 43 \\
\hline Banks & Metro Bank & 80 & $\begin{array}{l}\text { Goldman } \\
\text { Sachs }\end{array}$ & 5 & 34 \\
\hline Airlines & Southwest & 62 & $\begin{array}{l}\text { American } \\
\text { Airlines }\end{array}$ & 3 & 27 \\
\hline
\end{tabular}

Source: https://npsbenchmarks.com/industry/consumer_brands

\subsection{Research Objectives}

The research aims at assessing the "net promoter scores" of on-line retail industry - specifically the scores of the top three major players in the industry. Specifically the objectives of this research are:

- To assess the NPS scores of the following companies/brands of on-line retail

- Flipkart, Amazon and Myntra,

- To assess the key factors the 'promoter' customers consider while rating the service provider

- To assess the key factors the 'detractor' customers consider while rating the service provider

- To identify the factors that the service providers can pursue to earn customer satisfaction and loyalty

\subsection{Descriptive Research}

Descriptive research is used to "describe" a subject, situation, phenomenon or behaviour. They are generally used in studies that are concerned with finding out "what is". NPS research is essentially descriptive research that helps in observing and describing the customers' satisfaction and loyalty. NPS survey, de facto consists of only three questions - the first measures customer loyalty score and is quantitative and the second and third question gives the critical feedback and is qualitative.

\subsection{Questionnaire Design}

The questionnaire had four parts - the first part consisted of demographic details and the next three parts consisted typical NPS questions targeted at on-line retail customers. There were four key questions:

1. Identifying the service provider the respondent uses most often

2. NPS tool Likert scale (with a scale of 0 to 11 )

3. Feedback on the reason for the respondent's rating and

4. What the respondents look for in the company to ensure highest score on NPS scale (of customer satisfaction/loyalty)

\subsection{Sampling and Data Collection}

A research of this nature will be relevant only if the data is collected on a "pan India" basis. Accordingly, the data was collected from the following cities:

Ahmedabad

Benguluru

Bhubaneshwar

Bikaner

Delhi

Hubli

Hyderabad 
Kochi

Kolkata

Mumbai

Vizag

The total sample size was 1118 . However, the number of samples per service provider varied between 99 and 418.

\section{Data Analysis}

The net promoter score analysis is a simple percentage analysis and hence no statistical tools were used in analysing the data. It should be noted that the NPS score in the chart are given in fractions, whereas the NPS is generally rounded off (Table 2 \& Figure1).

Table 2. Net Promoter score - online retail - national data

\begin{tabular}{|l|l|l|l|l|l|l|}
\hline $\begin{array}{l}\text { Service } \\
\text { Provider }\end{array}$ & Total respondents & Detractors & Passives & Promoters & $\begin{array}{l}\text { NPS } \\
\text { Score }\end{array}$ & $\begin{array}{l}\text { NPS Score } \\
\text { (rounded off) }\end{array}$ \\
\hline Amazon & 418 & 41 & 157 & 220 & 42.82 & 43 \\
\hline Flipkart & 286 & 42 & 139 & 105 & 22.03 & 22 \\
\hline Myntra & 99 & 16 & 39 & 44 & 28.28 & 28 \\
\hline Others & 315 & 61 & 150 & 104 & 13.65 & 14 \\
\hline Total & $\mathbf{1 1 1 8}$ & $\mathbf{1 6 0}$ & $\mathbf{4 8 5}$ & $\mathbf{4 7 3}$ & 28.00 & 28 \\
\hline
\end{tabular}

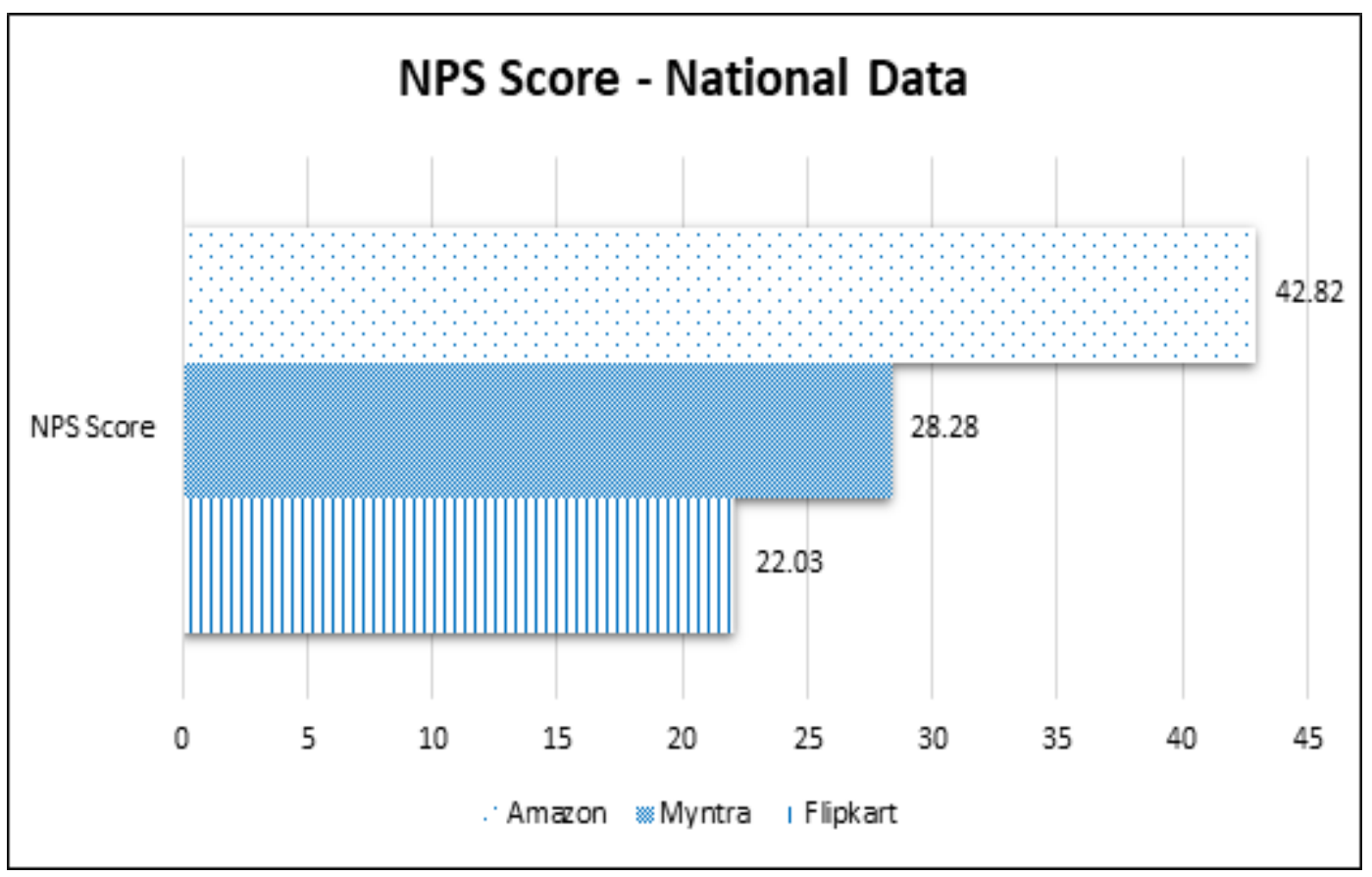

Figure 1. NPS Score - National Data 
Table 3. Net promoter score - online retail - Bangalore data

\begin{tabular}{|l|l|l|l|l|l|l|}
\hline $\begin{array}{l}\text { Service } \\
\text { Provider }\end{array}$ & Total respondents & Detractors & Passives & Promoters & $\begin{array}{l}\text { NPS } \\
\text { Score }\end{array}$ & $\begin{array}{l}\text { NPS Score } \\
\text { (rounded off) }\end{array}$ \\
\hline Amazon & 141 & 12 & 52 & 77 & 46.10 & 46 \\
\hline Flipkart & 75 & 5 & 38 & 32 & 36.00 & 36 \\
\hline Myntra & 30 & 1 & 15 & 14 & 43.33 & 43 \\
\hline Others & 112 & 14 & 53 & 45 & 27.68 & 28 \\
\hline Total & 358 & 32 & 158 & 168 & 37.99 & 38 \\
\hline
\end{tabular}

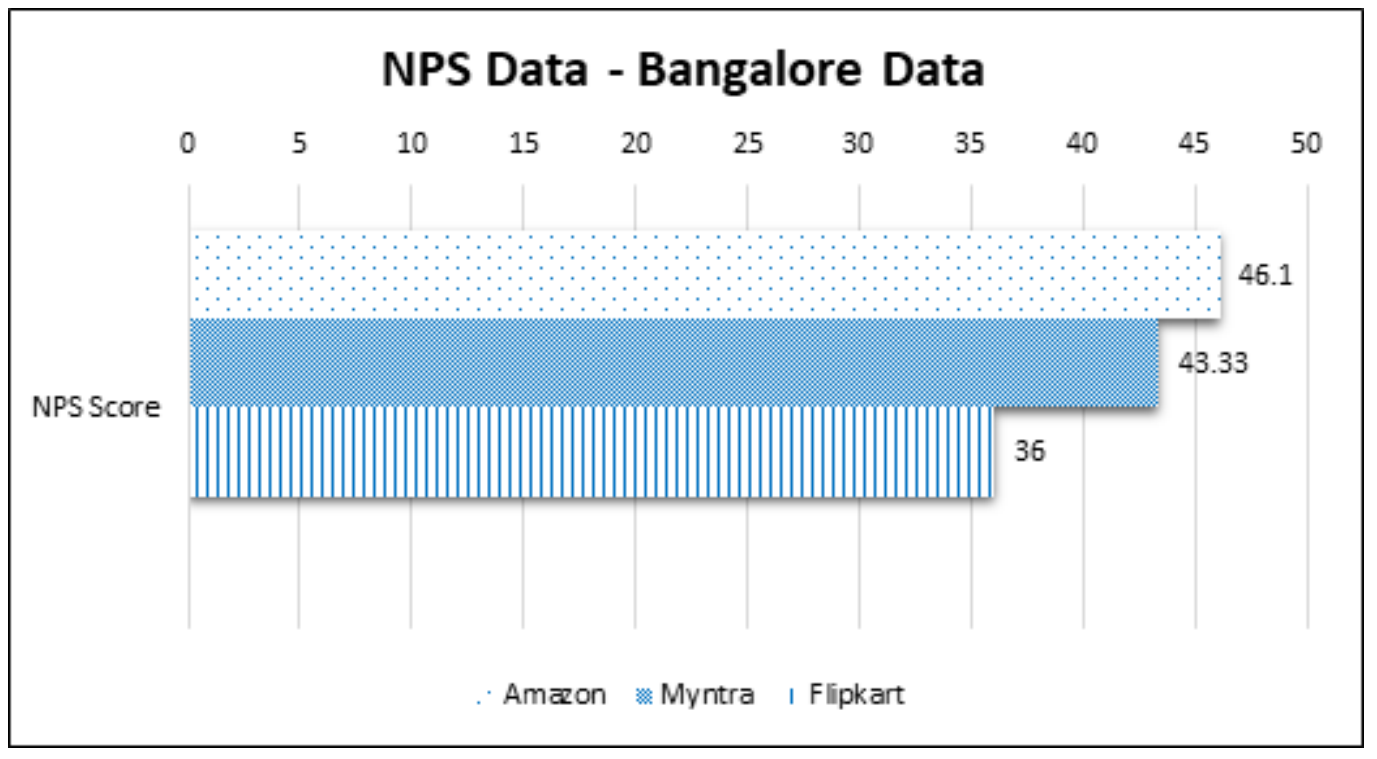

Figure 2. NPS data - Bangalore data.

Table 4. Reason(s) for promoter customers of online retail for giving the score

\begin{tabular}{|c|c|c|c|c|c|c|c|c|}
\hline \multirow[b]{2}{*}{$\begin{array}{l}\text { Service } \\
\text { Provider }\end{array}$} & \multicolumn{8}{|c|}{ Frequencies } \\
\hline & Nos. & $\begin{array}{l}\text { Delivery } \\
\text { Speed }\end{array}$ & $\begin{array}{l}\text { Ease of } \\
\text { Refund }\end{array}$ & Offers & Price & $\begin{array}{l}\text { Ease of } \\
\text { Search }\end{array}$ & Package & Quality \\
\hline Amazon & 220 & 116 & 57 & 40 & 34 & 40 & 55 & 60 \\
\hline Flipkart & 105 & 48 & 32 & 33 & 13 & 17 & 28 & 19 \\
\hline Myntra & 44 & 15 & 24 & 9 & 10 & 7 & 5 & 10 \\
\hline \multicolumn{9}{|c|}{ Percentage } \\
\hline Amazon & 220 & 52.73 & 25.91 & 18.18 & 15.45 & 18.18 & 25.00 & 27.27 \\
\hline Flipkart & 105 & 45.71 & 30.48 & 31.43 & 12.38 & 16.19 & 26.67 & 18.10 \\
\hline Myntra & 44 & 34.09 & 54.55 & 20.45 & 22.73 & 15.91 & 11.36 & 22.73 \\
\hline
\end{tabular}




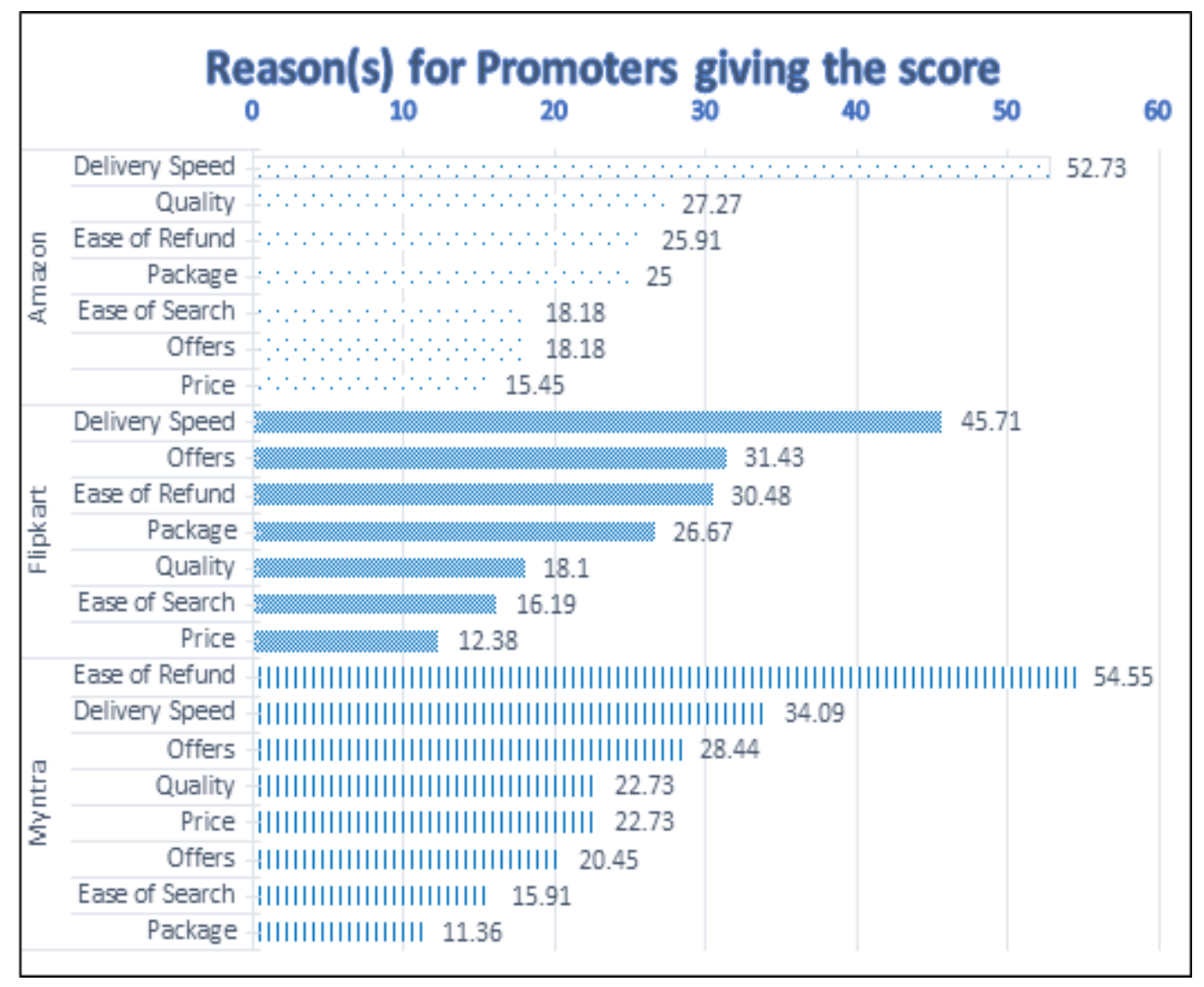

Figure 3. Reason(s) for promoters giving the score.

Table 5. Reason(s) for detractors/passives customers of online retail for giving the score

\begin{tabular}{|c|c|c|c|c|c|c|c|c|}
\hline & \multicolumn{8}{|c|}{ Frequencies } \\
\hline & Nos. & $\begin{array}{l}\text { Delivery } \\
\text { Speed }\end{array}$ & $\begin{array}{l}\text { Ease of } \\
\text { Refund }\end{array}$ & Offers & Price & $\begin{array}{l}\text { Ease of } \\
\text { Search }\end{array}$ & Package & Quality \\
\hline Amazon & 198 & 88 & 55 & 29 & 43 & 35 & 29 & 55 \\
\hline Flipkart & 181 & 53 & 52 & 46 & 40 & 31 & 42 & 61 \\
\hline Myntra & 55 & 17 & 24 & 11 & 8 & 8 & 11 & 13 \\
\hline \multicolumn{9}{|c|}{ Percentage } \\
\hline Amazon & 198 & 44.44 & 27.78 & 14.65 & 21.72 & 17.68 & 14.65 & 27.78 \\
\hline Flipkart & 181 & 29.28 & 28.73 & 25.41 & 22.10 & 17.13 & 23.20 & 33.70 \\
\hline Myntra & 55 & 30.91 & 43.64 & 20.00 & 14.55 & 14.55 & 20.00 & 23.64 \\
\hline
\end{tabular}




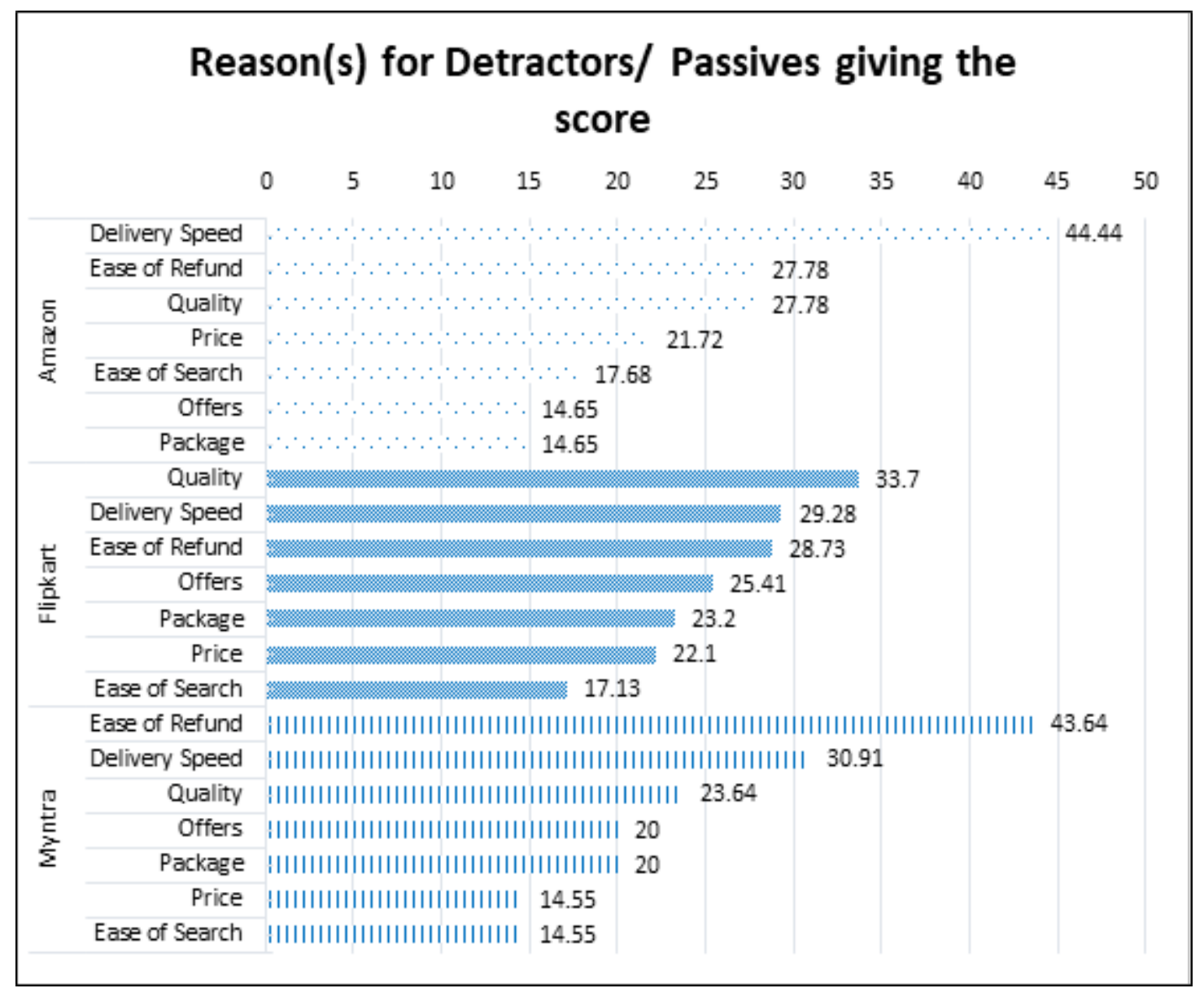

Figure 4. Reason(s) for detractors/passives giving the score.

Table 6. Which factor will enable customers of online retail to rate the service provider at '10'

\begin{tabular}{|c|c|c|c|c|c|c|c|c|c|}
\hline & & \multicolumn{9}{|c|}{ Frequency } \\
\cline { 2 - 10 } $\begin{array}{c}\text { Service } \\
\text { Provider }\end{array}$ & Nos. & $\begin{array}{c}\text { Delivery } \\
\text { Speed }\end{array}$ & $\begin{array}{c}\text { Ease of } \\
\text { Refund }\end{array}$ & Offers & Price $\begin{array}{c}\text { Ease of } \\
\text { Search }\end{array}$ & \multicolumn{2}{c|}{ Package } & Quality \\
\hline Amazon & 418 & 139 & 92 & 108 & 81 & 62 & 50 & 103 \\
\hline Flipkart & 286 & 102 & 72 & 43 & 35 & 43 & 34 & 69 \\
\hline Myntra & 99 & 28 & 28 & 26 & 32 & 15 & \multicolumn{2}{|c|}{6} & 31 \\
\hline Percentage & & & & & & & $12 \%$ & $25 \%$ \\
\hline Amazon & 418 & $33 \%$ & $22 \%$ & $26 \%$ & $19 \%$ & $15 \%$ & $12 \%$ & $24 \%$ \\
\hline Flipkart & 286 & $36 \%$ & $25 \%$ & $15 \%$ & $12 \%$ & $15 \%$ & \multicolumn{2}{|c|}{$12 \%$} \\
\hline Myntra & 99 & $28 \%$ & $28 \%$ & $26 \%$ & $32 \%$ & $15 \%$ & $6 \%$ & $31 \%$ \\
\hline
\end{tabular}




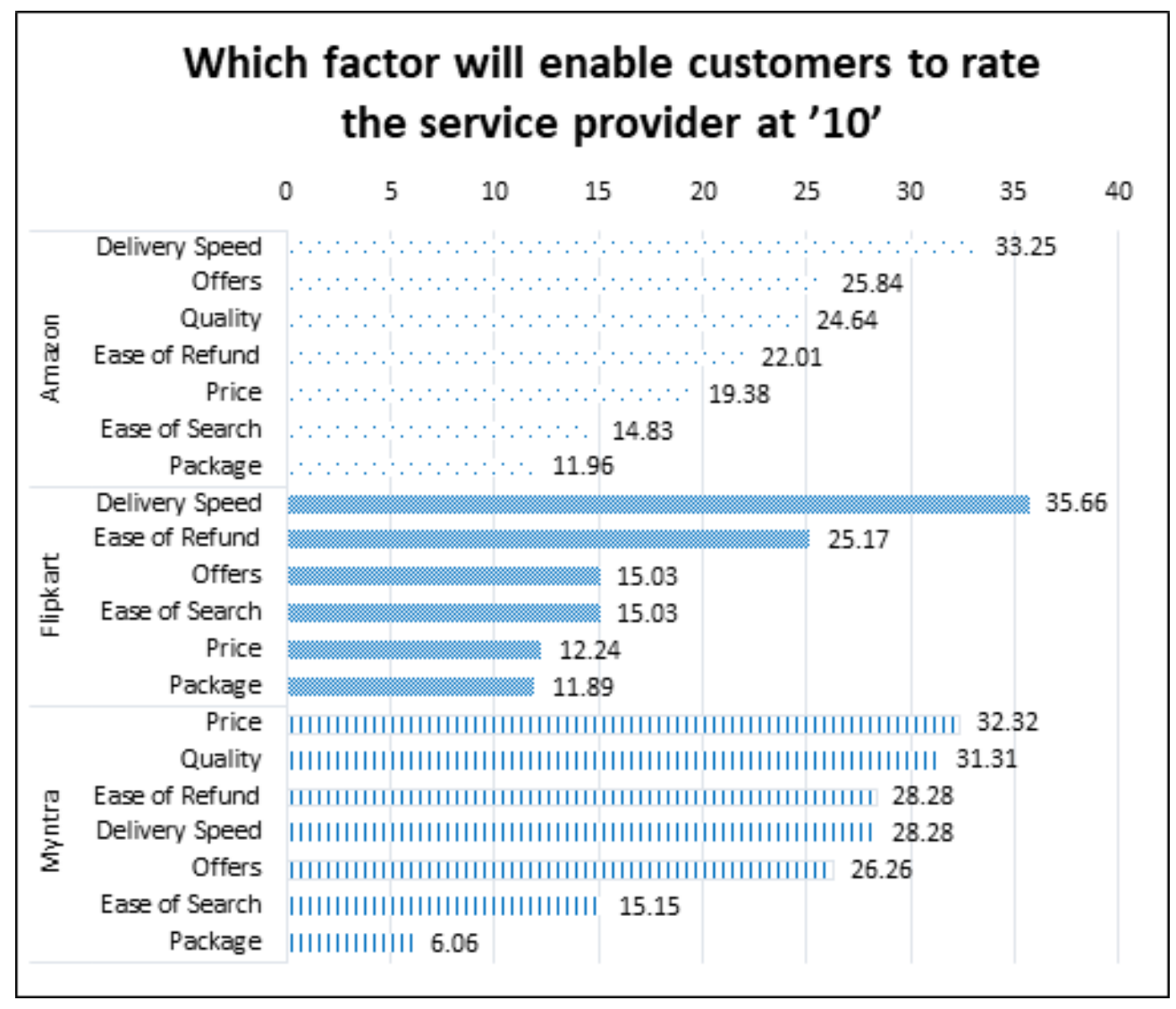

Figure 5. Which factor will enable customers to rate the service provider at '10'.

\section{Discussion}

The data very clearly shows that when it comes to customer satisfaction and loyalty as measured through Net Promoter Score, Amazon is ahead of other on-line retail companies. On analysing national data, as shown in (Table 2 \& Figure 1), Amazon has an NPS score of 43 compared to Flipkart's 22 and Myntra's 28. The NPS data of Bangalore also puts Amazon ahead with an NPS score of 46 as compared to Flipkart's 36 and Myntra's 43 (Table 3 \& Figure 2).

The data shows that NPS score of all three service providers in Bangalore are much ahead of their national scores. This could be because of better service and faster delivery in Bangalore compared to other locations. It is also pertinent to note that Myntra's NPS scores are ahead of Flipkart's scores nationally as well as in Bangalore.

While analysing the reasons for why the promoters gave the rating, they varied between service providers and the same is shown in (Table $4 \&$ Figure 3). Almost
$53 \%$ of the 'promoter' customers of Amazon and 46\% of the promoter customers of Flipkart have responded saying that the 'delivery speed' as the reason for giving the rating. This was followed by quality and ease of refund for Amazon, whereas it was offers and ease of refund for Flipkart. For Myntra, about 55\% of the respondents have said 'ease of refund' as the key reason for their rating. This was followed by 'delivery speed'.

Interestingly, while analysing the data of detractors/ passives, (Table $5 \&$ Figure 4) 'delivery speed' remained the biggest concern for Amazon customers whereas it was 'quality for Flipkart and 'ease of refund' for Myntra customers.

Also as a response to the question, "what factor will enable customers to rate the service providers at 10?", again largest percentage of customers of Amazon and Flipkart have indicated 'delivery speed' as the key factor, while Myntra customers had indicated 'price' (Table 6 \& Figure 5). 
The data clearly shows that if the services provider has to build a strong and loyal customer base, the factors that they should focus on are 'delivery speed', 'ease of refund', 'quality' and 'price' - in that order. This proves that price while remaining a key factor to attract the buyers it does not play a role in loyalty.

\section{Conclusion}

Though NPS has been used quite extensively by industry of all hues for its simplicity and ease of implementation, there are a few researchers who question the efficacy of NPS. Fisher and Kordupleski (2019) say that NPS does not provide any statistically reliable data on what customer's value. Also they say that NPS focuses on retaining customers and not winning them or retaining them and also NPS provides no competitive data. Also they aver that there is nothing called as 'passive' customers. Also their main concern is that the tool can be subjected to major statistical analysis.

While NPS tool has its own detractors, it should be noted that rarely will a company succeed or fail based on the specific metric it chooses for measuring customer satisfaction and loyalty. More than the metric, it is how the company uses the metric and improvises that matters. Ultimately, the company has to increase 'promoters' and decrease 'passives' and 'detractors'. NPS survey is quite simple and may not provide deep data. If one wants more insights, other survey methods or additional questions can be added to the survey.

All said and done, the tool has got the fancy of the leading organisations worldwide and is one of the most used tool for measuring customer loyalty. Highly customercentric companies like Amazon, Apple, Southwest Airlines, Costco, Flipkart, Standard Chartered Bank etc. have been using NPS for the past many years which itself is a proof for the tool's efficacy.

While study conducted by the organisations does not have any competitive scores, this research aims to study the net promoter scores of competing organisations also. The highest national NPS score, whom one can term as NPS leader in the online retailing is Amazon with NPS score of 43. The highest Bangalore NPS score stood at 46 for Amazon.

Some managers argue that NPS of above ' 0 ' is good since these shows that the promoters are more than detractors. Any score between 0 and 50 is supposed to be good, between 50 and 70 is purported to be excellent and above 70 is world class (Severson, 2016)

In comparison with US companies, Indian companies are not doing that bad. The top NPS score in US (Temkin Group - Q3, 2018) was 65. The average industry wide NPS score in consumer sector in US varies between 0 and 39. The author of NPS tool Reichheld (2003) says that to ensure world-class customer loyalty and attract fierce customer referrals, the companies should aim for NPS score of above 75. If this is the benchmark, Indian companies have some distance to cover before they can be termed 'excellent' service providers.

\section{References}

1. Aksoy, L. (2014). Linking satisfaction to share of deposits: An application of the Wallet Allocation Rule, International Journal of Bank Marketing, 32(1), 28-42. https://doi. org/10.1108/IJBM-03-2013-0025.

2. Alhassan, R. K., et al. (2016). Design and implementation of community engagement interventions towards healthcare quality improvement in Ghana: A methodological approach, Health Economics Review, 6, 49. https://doi. org/10.1186/s13561-016-0128-0.

3. Auh, S., Salisbury, L. C., \& Johnson, M. D. (2003). Order Effects in Customer Satisfaction Modelling, Journal of Marketing Management, 19(3/4), 379-400. https:// doi.org/10.1080/0267257X.2003.9728215, https://doi. org/10.1362/026725703321663700.

4. Bendle, N. T., \&d Bagga C. K. (2016). The Metrics That Marketers Muddle, MIT Sloan Management Review, 57(3), 73-82.

5. Bhattacharya, S., \& Mishra B. B. (2015). Evolution, growth and challenges in e-commerce industry: A case of India, SUMEDHA Journal of Management, 4(1), 45-58.

6. Cadotte, E. R., Woodruff, R. B., \& Jenkins, R. L. (1987). Expectations and norms in models of customer satisfaction, Journal of Marketing Research, 26, 305-314. https://doi. org/10.1177/002224378702400307.

7. Churchill, G. A., \& Surprenant, C. (1982). An investigation into the determinants of customer satisfaction, Journal of Marketing Research, 19(4), 491. https://doi. org/10.2307/3151722.

8. Coker, Brent L. S. (2013). Antecedents to website satisfaction, loyalty and word-of-mouth, Journal of Information Systems and Technology Management, 10(2), 209-218. https://doi. org/10.4301/S1807-17752013000200001.

9. Edvardsson, B., et al. (2000). The effects of satisfaction and loyalty on profits and growth: Products versus services, 
Total Quality Management, 11(7), 917-927. https://doi. org/10.1080/09544120050135461.

10. Faltejsková, O., et al. (2016). Net promoter score integration into the enterprise performance measurement and management system, Ekonomie a Management, 19(1), 93-106. https://doi.org/10.15240/tul/001/2016-1-007.

11. Fisher, N. I. and Kordupleski R. E. (2019). Good and bad market research: A critical review of net promoter score, Appl. Stochastic Models Bus. Ind., 35, 138-151. https://doi. org/10.1002/asmb.2417.

12. Fornell, Claes, et al. (1996). The American customer satisfaction index: Nature, purpose and findings, Journal of Marketing, 60, 7-18. https://doi. org/10.1177/002224299606000403.

13. Grisaffe, D. B. (2007). Questions about the ultimate question: Conceptual considerations in evaluating Reicheld's NPS, Journal of Consumer Satisfaction, Dissatisfaction and Complaining Behavior, 20, 36-53.

14. Jamal, A., \& Anastasiadou, K. (2009). Investigating the effects of service quality dimensions and expertise on loyalty, European Journal of Marketing, 43(3/4), 398-420. https://doi.org/10.1108/03090560910935497.

15. Jana, A. (2014). Impact of the attributes of service quality on customer satisfaction and the Interrelationship among service quality, customer satisfaction and customer loyalty: A study of casual dining at Ranchi, Journal of Hospitality Application and Research, 9, 2.

16. Jang, J. H. et al. (2013). The effects of relationship benefit on relationship quality and store loyalty from convergence environments-NPS analysis and moderating effects, Electronics Commerce Research. 13, 291-315. https://doi. org/10.1007/s10660-013-9117-0.

17. Keiningham, T. L. (2008). A holistic examination of net promoter, Database Marketing \& Customer Strategy Management, 15(2), 79-90. https://doi.org/10.1057/ dbm.2008.4.

18. Klopotan, I., et al. (2016). Impact of Income on customers' loyalty: Are customers with higher income more loyal? Business Systems Research, 7(1), 81-88. https://doi. org/10.1515/bsrj-2016-0006.

19. Kursunluoglu, E. (2014). Shopping centre customer service: Creating customer satisfaction and loyalty, Marketing Intelligence and Planning, 32, 528-548. https://doi. org/10.1108/MIP-11-2012-0134.

20. McMullan, R. (2008). Customer loyalty: An empirical study, European Journal of Marketing, 42, 1084-1094. https://doi. org/10.1108/03090560810891154.

21. Mittal, B. (2016). Retrospective: why do customers switch? The dynamics of satisfaction versus loyalty, Journal of
Services Marketing, 569-575. https://doi.org/10.1108/JSM07-2016-0277.

22. Oliver, R. L. (2010). Satisfaction: A Behavioral Perspective on the Consumer - A Behavioral Perspective on the Consumer. M E Sharpe, Business \& Economics, Routledge, New York; p. 544. https://doi.org/10.4324/9781315700892

23. Perkins, D. S. (2012). Future directions in consumer satisfaction, dissatisfaction and complaining behaviour: So much more to come, Journal of Consumer Satisfaction, Dissatisfaction and Complaining Behavior, 25, 7-23.

24. Pollák, F., \& Dorcák, P. (2016). Selected e-commerce entities for cooperation, FAIMA Business and Management Journal, 4(4), 49-58.

25. Reichheld, F. F. (2003). The one number you need to grow, Harvard Business Review, 1-10. https://hbr.org/2003/12/ the-one-number-you-need-to-grow.

26. Reichheld, F. F. \& Markey, R. (2011). The Ultimate Question 2.0: How Net Promoter Companies Thrive in a CustomerDriven World. Boston, Mass, Harvard Business Press.

27. Severson, D. (2016). Retrieved on March 17, 2020. Retrieved from https://www.inc.com/dana-severson/whats-a-goodnet-promoter-score-hint-its-not-what-you-might-expect. html.

28. Sharif, K. (2008). Impact of information and communication technologies on sales representative internal and external relationships - A study of the UK pharmaceutical sector, Journal of Medical Marketing, 8(4), 341-355. https://doi. org/10.1057/jmm.2008.13.

29. Shrivastava, A., et al. (2012). Study of Customer service on customer loyalty with reference to telecommunication industry in Sagar, International Journal of Management Prudence, 4(2), 103-109.

30. Temkin Group - Q3 (2018). Consumer Benchmark Survey - Retrieved on March 19, 2020. Retrieved from https:// experiencematters.blog/2018/10/01/report-net-promoterscore-benchmark-study-2018/.

31. York, A. S. (2011). Patient, staff and physician satisfaction: A new model, instrument and their implications, International Journal of Health Care Quality Assuarnce, 24, 178-191. https://doi.org/10.1108/09526861111105121. PMid: 21456492.

32. Zameer, H. (2015). Impact of service quality, corporate image and customer satisfaction towards customers' perceived value in the banking sector in Pakistan, International Journal of Bank Marketing, 33, 442-456. https://doi.org/10.1108/IJBM-01-2014-0015.

33. Žnidar, K., et al. (2014). Business Application of the sociological and psychological aspects of communities of interest: The case of Nautical Tourism in Croatia, Management, 19(2), 45-61. 